\title{
Dániel Bodonyi
}

\section{Pathways of Desire}

\section{The Appearance of an Amorous "I" in Shakespeare's Procreation Sonnets}

\begin{abstract}
This paper looks at Shakespeare's procreation sonnets in an attempt to retrace the pathways that lead to the first appearance of the Sonnets' lyrical "I" in Sonnet 10. In doing so, it focuses on the narrative evolution of subjectivity in Sonnets 1-9, observing the postures and poetic devices the lyrical "I" adopts to make room for selfreference. Mapping the conventions and contradictions in the span of which the speaking subject attempts to find the voice with which to address his other, the paper highlights the unconventionality of the sonnets, arguing that they can be read, even today, as writerly texts: passionate utterances restored to and questioning the status of amorous poetry.
\end{abstract}

\section{Background}

"Make thee another self for love of me"

The question of whether Shakespeare's Sonnets are autobiographical or "merely" literary exercises has dogged poets, readers and Shakespeare scholars alike for centuries. Indeed, as Kenneth Muir and others before him have pointed out, it is not unheard of for a single commentator to have held both positions at the same time:

The curious change of heart undergone by Sir Sidney Lee with regard to Shakespeare's Sonnets has been mentioned by Hyder E. Rollins and S. Schoenbaum. He began by claiming that Mr W.H. was William Herbert and ended by asserting with equal vehemence that he was the Earl of Southampton. But this volte-face was less surprising than the extraordinary difference between his article in the Dictionary of National Biography as it appeared in England in 1897 and the version published in America in the same year. English readers were assured that the Sonnets were autobiographical; American readers were informed with equal confidence that they were "to a large extent . . . literary exercises."

1. Kenneth Muir, Shakespeare's Sonnets (Abingdon: Routledge, 2005), p. 30.

The AnaChronisT 17 (Winter 2012) 1-27 ISSN 1219-2589 (print) ISSN 2063-126X (web) 


\section{DÁNIEL BODONYI}

Without endeavoring to adjudicate this well-worn conflict between the likes of Wordsworth, Browning, Swinburne, Frye and others, this paper takes its starting point from the seminal works of Roland Barthes ${ }^{2}$ and Niklas Luhmann, 3 both of whom have described love as a discourse, "a symbolic code" 4 that one uses to convey and, as both Barthes and Luhmann have emphasized, create feelings of love, be they "genuine" or imitated, "made of truth" or uttered by the "false-speaking tongue" 5 of an assaying poet or an unfaithful paramour. With this distinction between love as a feeling and love as a discourse ${ }^{6}$ in mind, this paper will attempt to explore the ways in which the lyrical "I" of Shakespeare's Sonnets sneaks into the discourse in the first part of the so-called procreation sequence, arguing that these sonnets too, despite being the ones in the volume that are perhaps the most widely regarded as exercises in the literary conventions of the era, can be read amorously, as part of "a lover's discourse" that asserts itself by virtue of its being rooted in established conventions of love as much as by its tendency to contravene those very same conventions.

In exploring how the poetic first person is introduced in Shakespeare's procreation sonnets, I will be treating Sonnets 1-17 as a sequence within the sequence even though "that word, with its suggestions of linearity and its promise of unity, was not used of sonnet books in the period."7 The primary motivation for this is not thematic: the Erasmian argument for marriage, with its requisite imagery of ploughing and tilling, is only one (and by no means the most interesting) cohesive factor that encourages a sequential reading. Instead of treating these sonnets as variations on a static unifying theme, I will try to account for the narrative evolution of subjectivity apparent in the way personal pronouns are distributed in the sequence, with the first-person singular personal pronoun lurking entirely (if at times conspicuously) concealed throughout Sonnets 1-9, only to appear no less than 28 times in Sonnets 10-17. In what follows, I will be focusing primarily on the rhetorical and poetic tactics Shakespeare adopts in the first part of the sequence to make room for selfreference, leaving aside, for the most part, the equally interesting question of the effect the resulting discourse has on the first-person poetic persona of the second

2. Roland Barthes, A Lover's Discourse: Fragments, tr. Richard Howard (New York: Hill and Wang, 1979).

3. Niklas Luhmann, Love as Passion: The Codification of Intimacy (Stanford: Stanford UP, 1998).

4. Luhmann, p. 8.

5. Sonnet 138, in Colin Burrow, ed., The Oxford Shakespeare Complete Sonnets and Poems (Oxford and New York: Oxford University Press, 2002).

6. Cf. Luhmann, p. 8.

7. Burrow, ed., p. 110. 
part of the procreation sequence and of Shakespeare's Sonnets in general, which is an issue too large for this paper to address adequately in more detail.

\section{Introduction}

"And therefore, Reader, I myself am the subject of my book," Montaigne says in his short avis to his "honest" essays, and one could legitimately supplant myself with thyself in an imaginary preface to Shakespeare's Sonnets 1-9, which are as obsessed with the second-person singular position as meticulously they seem to hide the speaking subject. As shown in Tables 1 and 2, the "I" of the Sonnets does not surface at all until Sonnet 10, to take on a rather hefty role from that point on throughout the second part of the sequence in what might at first glance seem a drastic change of events.

\begin{tabular}{l|c|c|c|c|c} 
& Nominative & Objective & Reflexive & Possessive & Total \\
\hline 1st-person singular & 0 & 0 & 0 & $3^{*}$ & $3^{*}$ \\
\hline 2nd-person singular & 31 & 14 & 8 & 21 & 74 \\
\hline 3rd-person singular ${ }^{\dagger}$ & 7 & 4 & 1 & 14 & 26 \\
\hline 1st-person plural & $1^{\ddagger}$ & 0 & 0 & 0 & 1 \\
\hline 2nd-person plural & 0 & 0 & 0 & 0 & 0 \\
\hline 3rd-person plural & 2 & 0 & 0 & 2 & 4
\end{tabular}

* Printed between quotation marks in contemporary editions - though not in the (first) Quarto - these three occurrences of the first-person singular pronoun, all within the same two lines in Sonnet 2, are uttered on behalf of the young man. ${ }^{8}$

+ The gender of the third-person singular pronoun does not make a difference from the perspective of this analysis.

\# Not "we" as in "you and I," but "we" as in "we the world, people in general."

Table 1. The distribution of personal pronouns in Sonnets 1-9

\begin{tabular}{l|c|c|c|c|c} 
& Nominative & Objective & Reflexive & Possessive & Total \\
\hline 1st-person singular & 16 & 0 & 0 & 12 & 28 \\
\hline 2nd-person singular & 29 & 10 & 12 & 21 & 72 \\
\hline 3rd-person singular & 7 & 4 & 0 & 2 & 13 \\
\hline 1st-person plural & 0 & 0 & 0 & 0 & 0 \\
\hline 2nd-person plural & 0 & 0 & 0 & 0 & 0 \\
\hline 3rd-person plural & 1 & 1 & 0 & 3 & 5
\end{tabular}

Table 2. The distribution of personal pronouns in Sonnets 10-17

8. Cf. Burrow, ed., p. 384 . 


\section{DÁNIEL BODONYI}

Looking at the distribution of personal pronouns in the procreation sonnets, there are two more aspects of their use that attract attention. First, a decrease is clearly in evidence in the number of third-person singular pronouns in the second part of the sequence, which contrasts sharply with the almost entirely even distribution of the second-person singular and all of the plural pronoun forms among Sonnets 1-9 and Sonnets 10-17. Second, in what Colin Burrow, the editor of The Oxford Shakespeare Complete Sonnets and Poems, thinks "may mark an increase in intimacy,"9 the second-person singular pronoun form "thou" is replaced with "you" in Sonnet 13, and while the poetic ${ }^{10}$ "thou" returns briefly in Sonnet 14, "you" - "the normal form of address between educated Elizabethans" ${ }^{11}$ - is used throughout Sonnets $15^{-17}$.

In my analysis of Shakespeare's Sonnets 1-9, I will attempt to show that these phenomena (the sudden increase in the use of the first-person singular personal pronoun, the noticeable decrease in the use of the third-person singular pronoun, and the switch from "thou" to "you") are not random occurrences, but interdependent symptoms of a process of self-creation, in which a conventional allegory of selfcreation becomes its own allegory, engendering an amorous "I" quite akin to the paradigmatically unconventional subject that a contemporary reader might also recognize as the subject of "a lover's discourse." In doing so, I will analyze the interplay of metaphor and mimesis in Sonnets 1-9, drawing on as well as arguing against the claims laid down by Joel Fineman in his book titled Shakespeare's Perjured Eye: The Invention of Poetic Subjectivity in the Sonnets.

\section{Sonnets 1-9}

The starting point for Shakespeare's procreation sonnets is amitié, ${ }^{12}$ which, as opposed to the sexual and extra-marital folle amour ("mad love"), is a normative relationship rooted in benevolence and convention. Indeed, this distinction is partly what differentiates the young man sonnets from the dark lady sonnets for Fineman,

9. Burrow, ed., p. 406.

10. Burrow, ed., p. 406.

11. Burrow, ed., p. 406.

12. Michael Andrew Screech, ed., The Essays of Michel de Montaigne (London: Alan Lane, The Penguin Press, 1991), p. 205, "In Renaissance French amitié includes many affectionate relationships, ranging from father's love for his child (or for his brain-child) to the friendly services of a doctor or lawyer ... and to that rarest of lasting friendships which David shared with Jonathan ... Several terms are needed in English to render these different senses; they include friendship, loving-friendship, benevolence, affection, affectionate relationships and love." 
who regards the former as belonging to - or, at most, only implicitly questioning the Petrarchist tradition of ideal admiration based on mimetic or metaphorical likeness. ${ }^{13}$ There is much to support this argument, and Burrow is certainly unfair in his curt, barely half-page dismissal ${ }^{14}$ of Fineman's elaborate distinction between Shakespeare's implicit and explicit rebuttal of Petrarchist panegyric. However, this paper is not concerned with the difference between the young man and the dark lady sonnets, nor does it want to explain this difference in terms of homo- and heteroerotic desire. Its aim is to pinpoint the (explicit and implicit) ways in which mimesis and metaphor, both traditional devices of epideictic discourse, serve to deconstruct praise as soon as the "I" implicitly enters the picture, as it inevitably will. In addition, it will attempt to show that the resulting reluctance to panegyrize is the only legitimate answer an amorous "I" can give to keep true to his vision of both the object and the substance of his praise.

\section{Sonnet 1}

When first addressing the young man in Sonnet 1, Shakespeare evokes convention by using the personal pronoun "we" - a word that subsequently never recurs in the sequence. As a result, the speaker's voice is blurred by a multitude of voices echoing each other in a generalized statement: conventional content is delivered in an impersonal tone with the help of a commonplace metaphor ("beauty's rose"). On the rhetorical level, the poet presents himself as a disinterested spokesman for social consensus, representing the world's and the young man's allegedly interlinked interests while oscillating between tender reproach and unblushing praise. Binary opposites abound, and it is in the span of these that the speaking subject positions

13. Joel Fineman, Shakespeare's Perjured Eye: The Invention of Poetic Subjectivity in the Sonnets (Berkeley, Los Angeles, London: University of California Press, 1986), pp. 59-62.

14. Cf. Burrow, ed., p. 135. By arguing that "the poems which praise the young man painfully do not, as Fineman would have them, identify the lover with his object and deny difference," Burrow completely misstates Fineman's argument. Quite contrary to denying difference, Fineman actually claims that "the young man sonnets generate division when they redouble the unity and unities of an ideal and an idealizing poetics ... and import difference into the traditional phenomenology of likeness." (Fineman, p. 278) Instead of denying the young man sonnets their fair share of difference, Fineman argues that these sonnets only implicitly express the difference that the dark lady sonnets will "literally make" by explicitly asserting this difference to be the reason why the lover, his object and his verse are of "a new epoch in literary history." (Fineman, pp. 279-280) Burrow also jibes at Fineman's claim that Shakespeare "invented modern consciousness" in the dark lady sonnets, even though Fineman repeatedly offers "comes upon" as an alternative to "invents" throughout his analysis to qualify his claim. 


\section{DÁNIEL BODONYI}

itself as a caring, supporting, and unselfish - one is tempted to say, self-less sounding board.

So it might seem, that is, if one looks only at the propositional content. But what is the perlocutionary effect on the listener? Is the convincing convincing? The potential discrepancy between illocutionary content and perlocutionary effect will serve as the main theme for two of the procreation sonnets (Sonnet 8: "Music to hear, why hear'st thou music sadly?" and Sonnet 17: "Who will believe my verse in time to come"). While Sonnet 1 does not yet raise this issue explicitly, discussing its potential effects on the listener is important in determining what kind of speaking subject we have because, as Helen Vendler notes, we tend to define the speaker as one given to the characteristic speech-acts of the sonnets, of which many are already revealed in Sonnet 1.15 In my analysis of Sonnets 1-9, I will be relying on Stanley Cavell's definition of performative (illocutionary) utterances, according to which "a performative utterance is an offer of participation in the order of law." ${ }^{16}$ Then I will attempt to describe the shift that takes place in Sonnets 1-9 from performative to what Cavell calls passionate utterance, a mode of expression devoted to perlocutionary rather than illocutionary effects, constituting "an invitation to improvisation in the disorders of desire." 17

Cavell describes Austin's six conditions for the felicity of illocutionary utterance as follows:

(1) there must exist a conventional procedure for uttering certain words in certain contexts, (2) the particular persons and circumstances must be appropriate for the invocation of the procedure, (3) the procedure must be executed correctly and (4) completely, (5) where the procedure requires certain thoughts or feelings or intentions for the inauguration of consequential conduct, the parties must have those feelings or thoughts and intend so to conduct themselves, and further (6) actually so conduct themselves subsequently. ${ }^{18}$

In Sonnet 1, Shakespeare summons the conventions of amitie and praise, and casts these in a conventional form, that of the amorous sonnet, so that Austin's first condition for a felicitous performative utterance is seemingly in place. However, conventional content and conventional form quickly turn on one another as, appar-

15. Cf. Helen Vendler, The Art of Shakespeare's Sonnets (Cambridge, Massachusetts; London, England: The Belknap Press of Harvard University Press, 1998), p. 49.

16. Stanley Cavell, Philosophy the Day After Tomorrow (Cambridge, Massachusetts; London, England: The Belknap Press of Harvard University Press, 2005), p. 19.

17. Cavell, p. 19.

18. Cavell, p. 18. 
ently, the particular addressee fails to behave in a manner appropriate for the invocation of the procedure of praise, which therefore cannot be executed correctly and completely. To be praised felicitously, the young man must change his intentions and his subsequent conduct, the sonnet says - at least on the rhetorical level.

However, there is an underlying tension among the various layers of convention Shakespeare adopts that sends seismic waves through the body of the sonnet. First, the sonnet is addressed to a man, and while the love of two men for each other was not uncommon in pastoral poetry, ${ }^{19}$ its only other evidence in renaissance sonnets is found in Michelangelo. Second, the topos of procreation is also alien to the renaissance sonnet tradition, ${ }^{20}$ which defines the beloved as an unattainable incarnation of Venus and hence of "light, form, desirability, beauty, and objective proportion." ${ }^{21}$ While the young man of Sonnet 1 is said to meet all these criteria, Northrop Frye also draws attention to Shakespeare's "disturbing and strikingly original device of associating the loved one with Eros rather than Venus," ${ }^{22}$ Eros representing "heat, energy, desire, love, and subjective emotion" ${ }^{23}$ and acting primarily as "a source of love rather than a responding lover." 24

Indeed, there is plenty of metaphorical evidence in Sonnet 1 corroborating Frye's claim about a shift in the beloved's symbolic position. Although the young man is represented in the first quatrain as a fair creature of light, the second quatrain reveals that, in sharp contrast to Sidney's star-like Stella, he himself is the source of his flickering brightness. The image of the candle lays the groundwork for a metaphor of waste that, instead of the passion exhibited by the Petrarchist lover ${ }^{25}$ (his "heart's excess"), is used to describe the beloved's wasteful use of his own self, an excess that "begs all." ${ }^{26}$ This optical oscillation between the ideal image of the ideal and its negative, which Fineman calls an "excess of likeness," ${ }^{27}$ is what sets the scene for perlocutionary utterance, the deconstruction of praise, and the appearance of the

19. Cf. Northrop Frye, "How True a Twain," in The Riddle of Shakespeare's Sonnets, ed. Edward Hubler (London: Routledge \& Kegan Paul, 1962), 23-54, p. 36. Frye lists Virgil's Second Eclogue and the first eclogue in Spenser's The Shepheardes Calender as examples. 20. Cf. Fineman, pp. 250, 255.

21. Frye, p. 32.

22. Frye, p. 38.

23. Frye, p. 32.

24. Frye, p. 38.

25. Cf., for example, Petrarch's Sonnet CCII, in which "He pleads the excess of his passion in palliation of his fault."

26. William Shakespeare, "A Lover's Complaint," in The Oxford Shakespeare Complete Sonnets and Poems, ed. Colin Burrow (Oxford and New York: Oxford University Press, 2002), 693-717, p. 698.

27. Fineman, p. 247. 


\section{DÁNIEL BODONYI}

amorous "I" in Sonnets 1-9. What this paper will try to show is that this double vision, projected onto the young man's allegedly inequitable use of his qualities, is in fact an inevitable corollary of the lover's position and the condition ultimately legitimizing his discourse; in other words, that it is a structural rather than descriptive element.

\section{Sonnet 2}

Like Sonnet 1, Sonnet 2 also strikes a tone of common sense, but here the undercurrents of hunger, greed and death already lurking beneath the "tender" surface of Sonnet 1 loom larger on the poetic horizon. Since it does not associate "famine," "glutton" and "decease" with any specific time frame, Sonnet 1 might appear sufficiently benign to the good natured reader. But with the first reference to the Sonnets' lyrical "I" introduced in line 1 ("forty winters") and its military metaphors, Sonnet 2 is substantially more explicit in its siege of the second person singular position. The distribution of power between "thou" and "they" also appears to have changed: instead of being asked to "pity the world," the young man is now "being asked," that is, summoned to answer. Not only are the boundaries of the second person singular sphere subsequently blurred to accommodate another, apparently harmless being (a "fair child"), but the possessive also gains control over the nominative throughout the first two quatrains: "thy" is dominant over "thou," relegating the young man's existence to his capacity of relating to his externalized aesthetic qualities. The wedge forced between the morphemes of the reflexive pronoun "thyself" in Sonnet 1 ("Thyself thy foe, to thy sweet self too cruel") is thereby driven deeper, and will remain an effective tool in carving out the locus of self-expression for the lyrical "I" throughout the initial procreation sonnets.

The resulting feeling of fragility is further compounded by the exacerbation of the double vision first shown in Sonnet 1. In Sonnet 2, various shadows of selves appear and fade in rapid succession: we see the young man gazed at, and then looked down on; we see him trying to conjure up the image of his "own deep-sunken eyes;" and we see him and the world peering into the future at the ultrasound picture of his child as if it was a sepia reproduction of himself. What is hard to see, however, is how any of these phantom images, these blurred edges of time can make us see his blood warm when we know he will feel it cold. The sonnet's reasoning is lukewarm at best: it feels as though none of the young man's replicas could emulate what he is now, since neither the passing of his beauty, nor its potential rejuvenation is tangible at the present moment.

By introducing such temporal self-difference into the self-contained "withinness" of the beloved, Sonnet 2 succeeds in displacing the second person singular position. As Fineman notes: 
Turning upon himself, looking himself in his own I and eye, the young man discovers the death that "within thy own bud buriest thy content" (1). This "within" describes the same recessed and invert site and sight wherein, in sonnet 2, the young man's "beauty" and his "treasure" "lies": there "within thine own deep-sunken eyes," there as an "all-eating shame" and "thriftless praise." It is no exaggeration to say that this "within," this circumscribed bisection of the self-contained, traces out the "depths" of all the sonnets addressed to the young man, spreading itself out as a kind of striated, interior hollowness ${ }^{28}$

In other words, this "within" serves as what Georges Poulet would call the procreation sonnets' "point of departure," the initial and central experience "around which the entire work can be organized." ${ }^{29}$ By "[redoubling], with a difference, master images of sameness that traditionally objectify the poetics of the poetry of praise," 30 Sonnet 2 forces the young man to register "the frailty and fragmentation of the self in its exposure to the world." ${ }^{11}$ At the same time, this "awareness of the frailty of our link with the world," ${ }^{2}$ which manifests itself rhetorically as an attempt to spur the awakening of the young man's consciousness, also marks the appearance of a mind posing as time's master, a poetic consciousness that, in the mask of continuity and homogeneity, "[gathers] scattered fragments of time into a single moment and [endows] it with generative power." 33 However, this moment of generative tension, borne by the rhyming juxtaposition of "mine" and "thine" in lines 10 and 12, remains hidden from the world's prying eyes for the time being, as the present - this moment of anxious intimacy - is affirmed hypothetically, dependent on an answer that only the sonnet's "thou" "couldst" give. 34

\section{Sonnet 3}

The first condition of passionate (perlocutionary) utterance, Stanley Cavell says, is an absence of convention: "There is no conventional procedure for appealing to you to act in response to my expression of passion." ${ }_{35}$ By presenting traditional epideic-

28. Fineman, p. 248.

29. Paul De Man, Blindness and Insight: Essays in the Rhetoric of Contemporary Criticism (London: Methuen \& Co. Ltd, 1983), p. 81.

30. Fineman, p. 25.

31. De Man, p. 105.

32. De Man, p. 87.

33. De Man, p. 90.

34. Cf. Sonnet 2, line 10 ("If thou couldst answer").

35. Cavell, p. 18 


\section{DÁNIEL BODONYI}

tic discourse through the distorted prism of a genre-alien theme and the temporal difference brought into play in Sonnet 2, Shakespeare reframes the convention of homogeneous praise in a way that gives him "the standing to appeal to or to question" 36 the young man (in Sonnets 1 and 2, respectively) - Cavell's second condition of passionate utterance. Moreover, by scattering the young man's image among hypothesized "eyes" and different moments in time, the lyrical "I" gathers enough momentum to temporarily suspend convention and become the master of his addressee's image. This sets the scene for perlocutionary utterance, in which "the 'you' comes essentially into the picture," 37 in Sonnet 3.

If the present is what Sonnet 2 was hiding, it is also what rips apart, with compelling force, the veil of superimposed continuity in Sonnet 3. The first quatrain's emphatic "nows" are in sharp contrast with the pallid images of the-future-aspresent and the-present-as-past presented in the previous poem, with the number of verbs ${ }^{38}$ and the imperative mood of the first line also indicating urgency. These features evince what Stanley Cavell says are the further remaining conditions of passionate utterance: "In speaking from my passion I must actually be suffering the passion ... in order rightfully to ... Demand from you a response in kind, one you are in turn moved to offer, and moreover ... Now."

That the mimetic bisection of the beloved's withinness - effected in the mirror, through repeated entreaties to procreate and by a subtle rewriting of epideictic praise - is expressed passionately should come as no surprise. According to Poulet and Paul de Man, the "point of departure" is always "experienced as a moment of particularly strong emotional tension:" 39 like a passionate utterance, which is "backed by no conventional procedure," 40 the point of departure is "a present rooted in nothing." ${ }^{41}$ It is as the co-owner of such a passionate, unconventional "now" that an amorous "I" first makes its presence felt in Shakespeare's procreation sonnets.

Exhibiting the linguistic stage props of an amorous scene, Sonnet 3 concludes with a couplet that is "phrased almost as a death curse." 42 In sharp contrast to what Stephen Booth calls in his work on Shakespeare's Sonnets "the comfort of the cou-

36. Cavell, p. 18 .

37. Cavell, p. 180.

38. There are two verbs each in lines 1 and 4. Shakespeare often deploys lines with two predicates in the couplet, but the first three quatrains characteristically employ singlepredicate structures.

39. De Man, p. 89

40. Cavell, p. 181.

41. De Man, p. 90.

42. Vendler, p. 58. 
plet," 43 Sonnet 3 closes with what Roland Barthes says "each partner in the scene dreams of having:" 44 the last word. Yet, as Stanley Cavell notes, "in this mode of exchange [i.e., the perlocutionary], there is no final word, no uptake or turndown until a line is drawn, a withdrawal is effected, perhaps in turn to be revoked:" 45 "we see once again that only death can interrupt the Sentence, the Scene." ${ }^{66}$ In this staged (since hypothetical) argument, which hinges on the couplet's "if" which is the only thing that stops it from unfolding, the Sonnets' as-yet-implicit poetic "I" becomes the co-owner of the present by being the co-owner of the language of the scene:

When two subjects argue ... [they] are already married: for them the scene is an exercise of a right, the practice of a language of which they are coowners; each one in his turn, says the scene, which means: never you without me, and reciprocally. 47

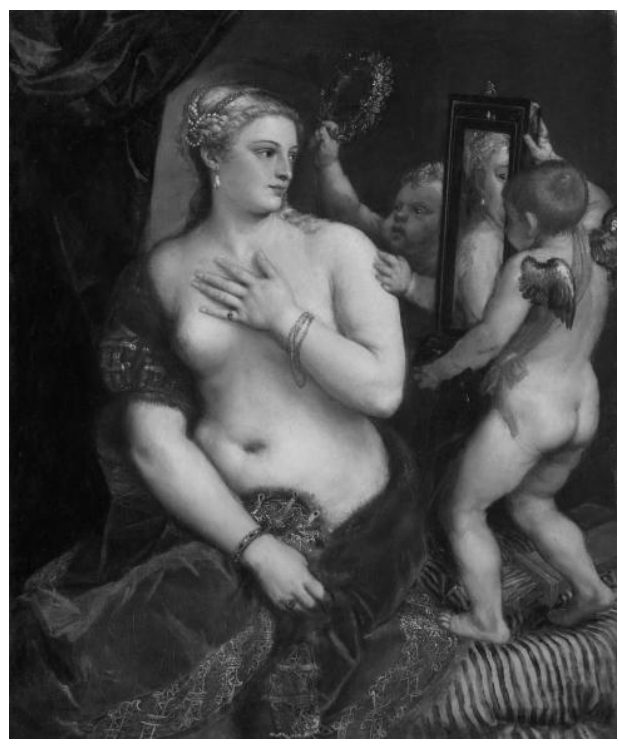

Figure 1. Titian's Venus with a Mirror

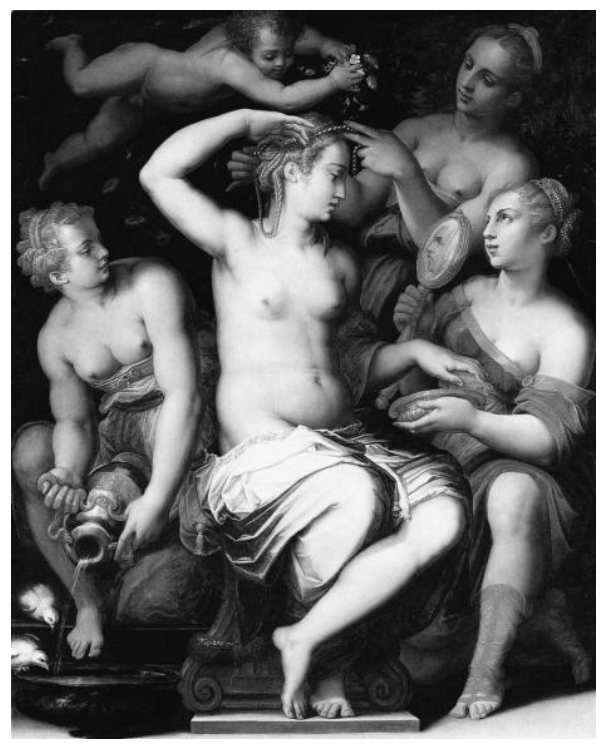

Figure 2. Vasari's Venus at Her Toilette

43. Cf. Stephen Booth, ed., Sonnets, (New Haven and London: Yale University Press, 1977), pp. 130-131. "The couplet concludes the poem ... ties off one set of loose ends ... [and] brings the reader's mind back to conceiving of experience in a single system.”

44. Barthes, pp. 207-208.

45. Cavell, p. 183.

46. Barthes, pp. 207-208.

47. Barthes, p. 204. 


\section{DÁNIEL BODONYI}

To visualize the lyrical "I's" position at and on this stage, one needs only to glimpse his eye's reflection in the mirror image of the first line's deliberately indefinite "face thou view'st." In renaissance painting, most notably in Vasari's The Toilet of Venus and Titian's Venus with a mirror, a peculiar phenomenon in picture perception, known as the Venus effect, comes into play "when a picture shows an actor and a mirror that are not placed along the observer's line of sight ... and when the actor's reflection in the mirror is visible to the observer" 48 - a setting similar to that staged by Sonnet 3. As noted by Bertamini, Latto and Spooner:

The problem is that the vantage point from which the scene is represented (as well as the vantage point of the viewer, were they to differ) is different from the vantage point of Venus. Therefore, if we see Venus's face nicely framed inside the mirror, she must see something quite different. If the painter reproduced what he saw, then the model must have seen the painter in the mirror. 49

In other words, even if we readers fail to register its presence in the scene, the lyrical "I's" reflection is there for the young man's eyes to see, visible in the glass in which we falsely perceive the young man to be looking at himself while what he sees is in fact the likeness of another face that his face is entreated to form.

\section{Sonnet 4}

By Sonnet 4, the Sonnets' poetic "I" has acquired a decidedly authoritative voice and affirmed its position as the co-owner of the young man's present, his image, and the language of confronting him to temporarily suspend his "withinness." The tone of voice and the "rigid isomorphism" ${ }^{\circ}$ of the rhetoric both reflect a firm footing in Sonnet 4: instead of the lover, we hear the master speak.

In his 1981-1982 lectures at the Collège de France, published under the title The Hermeneutics of the Subject, Michel Foucault gave a detailed account of what he termed "the care of the self" and "the soul-subject." What is at stake in these lectures is Foucault's primary concern in the works subsequent to Volume 1 of The History of Sexuality: the relation of the self to itself. In exploring the care of the self and the forms it takes in Greek philosophy, the word khrēsthai (use, usage), with its

48. Marco Bertamini, Richard Latto, Alice Spooner, "The Venus Effect: People's Understanding of Mirror Reflections in Paintings," in Perception 32 (2003), 593-599, p. 593.

49. Bertamini, Latto, Spooner, p. 595.

50. Cf. Vendler, p. 63, "The aesthetic value proposed here is a rigid isomorphism (each of the four hectoring questions occupies two lines, and three of the questions use the same phrase, why dost thou)." 
connotations of "having appropriate and legitimate relationships," ${ }^{11}$ is of primary importance to Foucault. The soul, he says, uses "the body, its organs and its tools" as well as itself, where "use" is not meant to designate "an instrumental relationship," but "the subject's singular, transcendent position, with regard to what surrounds him, to the objects available to him, but also to other people with whom he has a relationship, to his body itself, and finally to himself." ${ }_{2}^{2}$

The appropriate and legitimate use of one's self is also the axle around which Sonnet 4 revolves. Warning the young man about the dangers of disusing or misusing one's self, the poetic "I" puts himself in the master's position, which Foucault describes as follows:

The master is the person who cares about the subject's care for himself, and who finds in love for his disciple the possibility of caring for the disciple's care for himself. By loving the boy disinterestedly, he is then the source and model for the care the boy must have for himself as subject.53

What undermines this reading is, of course, the word "disinterestedly." Sonnet 4 is all about interest in the financial sense of the word: the poetic "I" wants his beautiful boy to be profitable. Acutely aware of his metaphorical investment in the subject, the master starts sounding rather like a pimp, as his concern for the young man's appropriate and legitimate use of his "sweet self" gradually acquires an increasingly inappropriate air. The sexual undertones of the enjambment at the end of the first line 54 and the word "traffic" in the third quatrain, together with the thematic innuendos brought into play by the metaphor of usury, 55 subvert the sonnet's rhetoric step by step even as it unfolds. Ideology and metaphor turn on one another, engendering the sonnet's unorthodox economics and equivocal ethics in which the young

51. Michel Foucault, The Hermeneutics of the Subject: Lectures at the Collège de France, 1981-82, ed. Frédéric Gros, François Ewald, Alessandro Fontana, Arnold I. Davidson, tr. Graham Burchell (New York: Palgrave Macmillan, 2005), p. 56.

52. Foucault, pp. 56-57.

53. Foucault, p. 59.

54. As Burrow notes on p. 388, "spend can mean 'ejaculate', and Spend | Upon thyself suggests masturbation."

55. As Fineman notes (p. 256), "Dante puts usurers and homosexuals in the same circle of hell, on the grounds that they both attempt to generate an unproductive profit ... by coupling kind with kind." The juxtaposition of usury and homosexuality is also familiar from The Merchant of Venice, while in Measure for Measure Pompey, the pimp, refers to prostitution as "the merriest usury" (III/2.6-11: "Twas never merry world, since, of two usuries, the merriest was put down, and the worser allowed by order of law a furred gown to keep him warm." Quoted in Marc Shell, Money, Language, and Thought (Berkeley, Los Angeles, London: University of California Press, 1982), p. 50. 


\section{DÁNIEL BODONYI}

man is both debtor and creditor and is simultaneously urged to imitate "the husband ..., who economizes his goods, his happiness," 56 and to give in to a more lucrative type of usury, characteristic of "the young lover who lavishes his time, his faculties, his fortune" 57 (his "bounteous largess") "without counting the cost." 58 This oscillation between the sonnet's normative illocutionary content and its disruptive perlocutionary effect culminates in a series of oxymorons, a usury of meaning59 that puts the poetic "I" in a paradoxical light: part a philosopher, part a pederast, the speaking subject is still at pains to hide the painting hand in the picture he is painting and thereby maintain the vacillation of the subject without which "there is no erotics." 60

\section{Sonnets 5 and 6}

Ostensibly, Sonnets 5 and 6 constitute a pair - a prelude and a fugue, the setting and the scene, the proverb and the personal implications of its meaning. Through a process of poetic distillation, an attempt is made to separate the components of the double voice and vision developed in the previous sonnets into two separate vessels: Sonnet 5 , the only sonnet in the procreation series entirely missing a second person singular personal pronoun, is generalized in its claim, abstract in its imagery and normative in its tone, while Sonnet 6 is personal in the extreme with its emphatic focus on "thou," direct with its references to breeding, worms and death, and passionate in tone and prosody.

Distillation is the central metaphor in both sonnets: cloaked as an alchemist, the poet is offering eternal youth and immortality to the young man together with a hundredfold increase in his "treasure" if only he were willing to consent to having his beauty distilled into an elixir of life, a "substance" that "lives sweet." As Northrop Frye remarks in How True a Twain:

[The Renaissance poet] was expected to turn his mind into an emotional laboratory and gain his experience there under high pressure and close observation. Literature provided him with a convention, and the convention

56. Barthes, p. 85 .

57. Barthes, p. 84 .

58. Barthes, p. 84 .

59. Akin to what Shell defines as "verbal usury," i.e., "the generation of an illegal - [or] unnatural - supplement to verbal meaning by the use of such methods as punning and flattering" (Shell, p. 49).

6o. Cf. Roland Barthes, The Grain of the Voice: Interviews 1962-1980, tr. Linda Coverdale (London: Jonathan Cape, 1985), p. 173, "There is no erotics without ... the vacillation of the subject: everything is in this subversion, this perturbation of grammar." 
supplied the literary categories and forms into which his amorphous emotions were to be poured. ${ }^{6}$

In Shakespeare's emotional laboratory, an experiment is made to extract the second person singular element from the vial ${ }^{62}$ of Sonnet 5 by construing the young man's eye and I as the place "where every eye doth dwell." This is achieved by the sonnet's allegorical abstraction of the personal and its personification of the abstract, and is also reflected in the sonnet's impersonal, almost factual tone, which culminates in the proverbially phrased couplet. ${ }^{63}$

The significance of Shakespeare's use of personification in Sonnet 5 and the couplet's proverbial phrasing can be understood in light of Brett Bourbon's analysis of two letters by Keats on the process of "soul-making." 64 In the first letter, Keats presents an allegory of the process of soul-making by personifying a rose whose life is "contingent on and limited by the opposing forces of an indifferent nature": 65

For instance suppose a rose to have sensation, it blooms on a beautiful morning, it enjoys itself, but then comes a cold wind, a hot sun - it cannot escape it, it cannot destroy its annoyances - they are as native to the world as itself - no more can man be happy than worldly elements will prey upon his nature. 66

In Bourbon's reading, the personification of the rose becomes an allegory of the conflict, on the one hand, between an indifferent nature and feeling ("those states of mind that are broadly characterized as intentional"), ${ }^{67}$ and on the other hand, "between a non-intentional account of the world and an intentional one, between what science describes and what art imagines." 68 As Bourbon concludes, such a description of soul-making paves the way for "[separating] our humanity from the non-

61. Frye, pp. 30-31.

62. Similarly to Frye, Vendler (p. 67) also conceives of the sonnet form and its conventions as the container into which "the emotionally labile contents of [the] sonnet" are poured. She develops this idea specifically in connection with line 10 of Sonnet 5 ("A liquid prisoner pent in walls of glass").

63. Cf. Vendler, p. 67, "The couplet imitates the pointed brevity of [a] proverb."

64. Cf. Brett Bourbon, Finding a Replacement for the Soul: Mind and Meaning in Literature and Philosophy (Cambridge, Massachusetts; London, England: Harvard University Press, 2004), pp. 29-35.

65. Bourbon, p. 31.

66. Keats, quoted in Bourbon, p. 30.

67. Bourbon, p. 31.

68. Bourbon, p. 31. 


\section{DÁNIEL BODONYI}

intentional, indifferent world of circumstance and nature"69 since "through our poetic imagination, which allows for this special recognition and figuration of the rose, we show ourselves as not indifferent to the fate of the rose in the way the cold wind is." 70

This master image of the human soul and its relationship to nature is also the starting point for Shakespeare's procreation sonnets ("beauty's rose"); however, Sonnet 5 turns the allegory inside out in a rather sinister manner. For what is personified in Sonnet 5 is no longer the rose; rather, "those hours" and "neverresting Time" - the once "gentle," once "hideous" face of nature playing a zero-sum game with a single participant. Without a tenor in evidence, the "sap" and "leaves" of line 7 are no longer able to function as metaphors independently; they are merely "remembrances" of the metaphors employed earlier in the procreation sequence as well as by other sonneteers, and hence the indication of the presence of a "gardening poet"71 rather than a description of his beloved's qualities. Unlike Daniel's "halfblown" 72 or Keats's blooming rose, the rose of Sonnet 5 is already dead, stillborn in a world that is "inert ..., cut off, thunderstruck - like a waste planet, a Nature uninhabited by man," 73 where the only kind of soul to be "distilled" is "a liquid prisoner pent in walls of glass," an "hourglass being," 74 which, in the disreality 75 of the poem and of love, is the lyrical "I" itself, 76 looking at the world that "plays at living behind a glass partition; [as] in an aquarium; ... close up and yet cut off." 77

As argued above, Sonnet 5 is an illustration of what is left in the vial after removing the second person singular element: the all-pervasive "bareness" it evokes is the lyrical "I's" image of a world "bereft" of his beloved's beauty. What is distilled in Sonnet 5 , therefore, is the lyrical "I's" very own soul as it wakes up to a world in

69. Bourbon, p. 32.

70. Bourbon, p. 32.

71. Fineman, p. 252.

72. Daniel, Sonnet XXXI

73. Barthes, p. 87.

74. Fineman, p. 249.

75. Cf. Barthes, pp. 90-91, "Sometimes the world is unreal ... sometimes it is disreal ... In the second case, I . . . lose reality, but no imaginary substitution will compensate me for this loss: ... I am not 'dreaming' (even of the other); I am not even in the Image-repertoire any longer. Everything is frozen, petrified, immutable, i.e., unsubstitutable: the Imagerepertoire is (temporarily) foreclosed."

76. As Fineman notes on p. 249, "the poet identifies himself, spatially, temporally, but also, as will be seen, sexually, with 'a liquid prisoner pent in walls of glass'. .., a dissolved liquidity within a brittle hardness, this hourglass being, again, the very image of the passing of an ideal time."

77. Barthes, p. 88. 
which his beloved's "lovely gaze" has replaced "every eye," functioning like a proscenium, a prosthetic eye without which the poet sees "bareness everywhere." This, of course, is not what Sonnet 5 says on the rhetorical level; it is what it does, or rather, what happens to it on the metaphorical level once the second person singular pronoun is extracted from its "substance." This is how - not so much "through [his] poetic imagination" but rather by pointing to that imagination's limits, the "walls of glass" imprisoning him - the lyrical "I" reveals itself "as not indifferent," in other words, as an amorous soul in the making.

In analyzing the proverbial pattern of Sonnet 5 's couplet and its implications on both the beloved's and the poet's "I" in Sonnet 6, it is worth noting that Sonnet 5 is only the second sonnet so far in the procreation series whose couplet does not rhyme "thee" with "be." In Fineman's reading, "the poet's rhyming 'thee' ... with "be" 78 takes its force from the fact that "at the beginning of the young man sonnets the young man ... is presented as the (somewhat disturbing) image of identity per se"79 and consequently "as an ego ideal - an ideal, that is, of what it is to be an ego or an 'I." "8o Furthermore, this idealization of the young man's self, Fineman argues, is contingent upon the young man's ideal duplication of his own self: "the young man is a copy that ideally should be copied," 81 which according to Fineman is "the logic on which all the procreation arguments depend." 82

In the following, drawing upon Brett Bourbon's analysis of another letter by Keats on soul-making, I will argue for an alternative image of the young man's identity and of the lyrical "I's" image of "identity per se" - one that is modeled on the relationship between Sonnet 5's couplet, understood as a proverb, and Sonnet 6, understood as a genuinely passionate but at the same time deliberately exaggerated plea to live out the meaning of that proverb. In addition, I will argue that this alternative image of identity is not contrary to the one Fineman describes in his analysis of the lyrical "I's" image of identity at the beginning of the procreation sonnets, but rather a corollary of how the lyrical "I" gains traction as the procreation narrative unfolds.

"Nothing ever becomes real till it is experienced - Even a proverb is no proverb to you till your life has illustrated it," says Keats in his letter, ${ }^{83}$ "[modeling] the relation between a life and a proverb ... on that between picture and text." ${ }^{84}$ In Bourbon's interpretation,

78. Fineman, p. 206.

79. Fineman, p. 206.

8o. Fineman, p. 206.

81. Fineman, p. 206.

82. Fineman, p. 206.

83. Quoted in Bourbon, p. 32.

84. Bourbon, p. 32. 


\section{DÁNIEL BODONYI}

[a] proverb becomes a proverb when my life illustrates it. The proverb is a type, and our experience - our life - is a token of that type... Such proverbs are meant to be the means of guidance; they provide vectors for our understanding. If our lives illustrate them, then our lives are not meaningless. Illustration gives sense to that which is illustrated; it is not simply an example but a version. ${ }^{85}$

It follows from this logic that if Sonnet 6 is read as the lyrical "I's" plea for the young man to live out the meaning of Sonnet 5 's couplet, then what the lyrical "I" urges the young man to produce in Sonnet 6 is not an ideal copy of his own self but rather an illustration of the lyrical "I's" formulation of how an ideal process of selfduplication should take place. This is consistent with the way Fineman develops his argument by pointing out that

it cannot be said that the poet identifies himself with the young man. Rather, what the poet reproduces is the young man's reproduction. And this repetition of repetition adds a wrinkle to the poet's project. Developing his praise through the theme of procreation, identifying his praise with the young man's "succession," the poet does not epideictically point to the young man: instead, he points to the young man's epideictic pointing. ${ }^{86}$

But to what extent is that pointing - i.e., the lyrical "I's" pointing to the young man's duplication of his self - epideictic, and precisely what kind of self-duplication does the lyrical "I" point to in Sonnet 6? Why is it that, as Helen Vendler notes, ${ }^{87}$ Sonnet 6 develops the procreation argument in such a "labored" and "fanciful" manner? And what explains the fact that, as Northrop Frye remarks, although "the youth is urged to marry as the only legal means of producing offspring, ... apparently any woman will do [and] it is not suggested that he should fall in love?"88

I believe there is a straightforward answer to all of these questions; one that might be said to do more justice to the Sonnets than Vendler's claim about Shakespeare being "entranced by fancifulness" 89 or Frye's charge that "the poet ... does not lift a metrical foot to make the youth a credible or interesting person." 90 The

85. Bourbon, pp. 33-34.

86. Fineman, p. 207.

87. Vendler, p. 72, "In this rather labored conceit of interest-bearing funds, a play - deliberately situated in the tenth line - on a posterity of ten producing a posterity of ten times that number reveals the degree to which Shakespeare could be entranced by fancifulness."

88. Frye, p. 26, my italics.

89. Vendler, p. 72 , cf. footnote 83 for the full quote.

90. Frye, p. 27. 
argument I would like to propose is a logical extension of Vendler's claim that the play on the ten-times-tenfold multiplication of the young man's reproduction is "deliberately situated in the tenth line" 91 to the "fancifulness" of the play. Indeed, if we contend that this play on words and numbers is consciously placed where it is, it becomes rather difficult to maintain that the fancifulness of its placement somehow escaped the author's attention without implying that Sonnet 6 represents a temporary failure in the poet's aesthetic judgment (which is essentially what Vendler claims). Instead, it makes more sense to posit that Shakespeare deliberately deflates the procreation argument in Sonnet 6 by artificially inflating the sonnet's rhetoric as well as the value of the promised reproductive profit.

Such a reading is also consistent with my previous statement that Sonnet 6 is not meant to impel the young man to copy his own self by reproductive means but to illustrate the distillatory process of self-creation described in Sonnet 5's couplet. In Sonnet 6 , the procreation argument is what Vendler says it is: a "labored conceit,"92 which is precisely why, in Frye's words, "any woman will do" 93 ("Make sweet some vial; treasure thou some place") and, as Vendler claims, the sonnet's "climax ... is less than convincing." 94 By presenting the procreation argument as an exaggerated and therefore aesthetically discreditable way of duplicating one's self, Sonnet 6 contrasts reproduction with self-duplication through distillation, that is, with making a soul by illustrating through one's own life a proverb on self-duplication through distillation. What Sonnet 6 reveals through its apparent mimicking of the procreation argument, therefore, is that the procreation sonnets do not, in fact, point to the young man's progeny epideictically. The truth of Sonnet 6 does not lie in reproduction, but is to be distilled by replicating the experiment carried out in Sonnet 5 the other way round.

While Sonnet 5 attempted to extract the second person singular element from the vial, Sonnet 6 replicates the process by attempting to do the opposite, thereby creating a compound in which "thou" has an overwhelming share: the second person singular personal pronoun appears in the sonnet no less than 14 times in five different forms. However, no distillation process that involves two elements with different characteristics is ideal: "it is not possible to completely purify a mixture of components by distillation." 95 Just as a droplet of "thou" is detectable in the gentleness of the opening lines of Sonnet 5 (since "Those hours that with gentle work did frame / The lovely gaze" can be gentle only insofar as they mirror the tenderness

91. Vendler, p. 72, cf. footnote 83 for the full quote.

92. Vendler, p. 72, cf. footnote 83 for the full quote.

93. Frye, p. 26.

94. Vendler, p. 72.

95. Pankaj Madan, Sangeeta Madan, ed., Global Encyclopaedia of Environmental Science, Technology and Management (New Delhi: Global Vision Publishing House, 2009), p. 330 


\section{DÁNIEL BODONYI}

with which the lyrical "I" frames his beloved's image), so a trace of the lyrical "I" is left in Sonnet 6, resulting in an ever more explosive mixture.

What these two experiments reveal through the difference in tone between the two sonnets is that it is the second person singular component that makes the compound volatile: "thou" is what ravishes and engulfs the lyrical "I." As Roland Barthes points out, this is symptomatic of a shift that has taken place in the lover's symbolic position since "the archaic time" 96 when the lover was conceived of as the "conquering, ravishing, capturing" ${ }^{97}$ party:

[I]n the ancient myth, the ravisher is active, he wants to seize his prey, he is the subject of the rape (of which the object is a Woman, as we know, invariably passive); in the modern myth (that of love-as-passion), the contrary is the case: the ravisher wants nothing, does nothing; he is motionless (as any image), and it is the ravished object who is the real subject of the rape; the object of capture becomes the subject of love; and the subject of the conquest moves into the class of loved object. 98

The "distillative" - that is, metaphorical rather than literal - reading of Sonnets 5 and 6 proposed in this paper, therefore, provides further proof of Fineman's argument that there is something fundamentally new about the way the subject of Shakespeare's Sonnets treats the idealizing tradition of sonneteering praise, portending the drift towards the symbolic positioning of the amorous subject as the subject of love-as-passion.

In addition, such a reading also underlines how Shakespeare's practice of mimesis breaks with idealized imitatio as rather than perceiving Sonnet 6 as an appeal to the young man to produce a "thinglike copy,"99 it sees "the activity of a subject which models itself according to a given prototype" 100 - a soul in the making, "making [itself] similar to an Other"101 and thereby acting as a prototype for the other's soul-making. Such a concept of imitation can be considered closer to Coleridge's "alchemic" mimesis than to Sidney's "speaking picture"102 in that it "consists ... in

96. Barthes, p. 188.

97. Barthes, p. 188.

98. Barthes, p. 188

99. Michael Cahn, "Subversive Mimesis: T. W. Adorno and the Modern Impasse of Critique," in Mimesis in Contemporary Theory, Volume 1, ed. Mihai Spariosu, (Philadelphia; Amsterdam: John Benjamins Publishing Company, 1984), 27-64, p. 34.

100. Cahn, p. 34.

101. Cahn, p. 34.

102. Philip Sidney, "The Defence of Poesy," in Renaissance Literature: An anthology, ed. John Hunter, Michael Payne (Oxford: Blackwell Publishing, 2003), p. 505; "Poesy therefore 
the interfusion of the SAME throughout the radically DIFFERENT, or of the different throughout a base radically the same" 103 rather than in "counterfeiting"104 in an attempt "to teach and delight." ${ }^{105}$ Therefore, we see again in Shakespeare's use of mimesis how the Sonnets put familiar poetic devices to work in radically different ways, this time by making metaphor the basis for mimesis and thereby using poetic imitation to point to the presence of a lyrical "I" as it frames reality ${ }^{106}$ rather than to an ideally copied (less than) ideal beloved.

That this lyrical "I" is the subject of love-as-passion - paradoxically, perhaps, to the contemporary reader - is also betrayed by his entreaties for his beloved to marry someone else. As Niklas Luhmann notes in Love as Passion: The Codification of Intimacy, the (societal) freedom to choose one's lover, which emerged in the seventeenth century as a key driver for the development of a semantic code for amour passion $^{107}$ and which, as this paper argues in Fineman's wake, also informs the problematization of amorous subjectivity in Shakespeare's Sonnets, was contingent on one crucial condition: "It cannot be emphasized enough that the freedom to choose someone to love applies to the extra-marital relationships of married persons. . Freedom thus began with marriage." ${ }^{108}$ With this in mind, a parallel reading of Sonnet 6 comes into play in which marriage is merely a pretext, a metaphorical offshore account through which the amorous "I" can pay a "willing loan" and lay claim to his beloved without being accused of "forbidden usury."

\section{Sonnet 7}

"Sonnet 7 has little to recommend it, imaginatively; both the conceit of the sun's predictable day-long jour-ney ... and the conceit of the fall of favorites from public respect are well-worn topics," 109 Helen Vendler says about Sonnet 7 in

is an art of imitation, for so Aristotle termeth it in the word mimesis . . to speak metaphorically, a speaking picture - with this end, to teach and delight."

103. Samuel Taylor Coleridge, The Works of Samuel Taylor Coleridge, Prose and Verse:

Complete in One Volume (Philadelphia: Thomas, Cowperthwait \& Co., 1840), p. 324.

104. Sidney, in Hunter, Payne, ed., p. 505.

105. Sidney, in Hunter, Payne, ed., p. 505.

106. Cf. Michael Davis, The Poetry of Philosophy: On Aristotle's Poetics (South Bend, Indiana: St Augustine's Press, 1999), p. 3, "Imitation always involves selecting something from the continuum of experience, thus giving boundaries to what really has no beginning or end. Mimêsis involves a framing of reality that announces that what is contained within the frame is not simply real. Thus the more 'real' the imitation the more fraudulent it becomes."

107. Cf. Luhmann, p. 48.

108. Luhmann, p. 50.

109. Vendler, pp. 76-77. 


\section{DÁNIEL BODONYI}

what Fineman would agree is an accurate description of "a reader's first responses to the poem":

In general terms the sonnet's point could not be clearer. The third quatrain follows on the octave like the night the day, but only so the couplet can in turn assure us that the young man's son revives the young man's sun. As in all the other procreation sonnets, therefore, we are invited to identify the young man with his issue, for this will make the young once again a "newappearing sight" whose reappearance reconverts "the eyes ('fore duteous) [that] now converted are." ... And it is this reasoning, as much as the implicit, though significantly never explicit, rhyme of "sun" with "son," that governs a reader's first responses to the poem. ${ }^{110}$

However, as Fineman goes on to describe, "by likening the son to both a youthful and an aged brightness, ... sonnet 7 interferes with, even as it argues for, the sameness of the young man's repetition," ${ }^{111}$ thereby bringing into play a "diagonal" reading of the poem that causes "the reader [to experience] a difference, not a likeness, in the 'imitation' that he reads about." "12 Once again, as seen in Sonnet 6, Shakespeare's use of mimesis is such that it "[identifies] likeness with difference." 113

Nevertheless, in spite of all its elaborate ingenuity, Shakespeare's use of imitation as a differentiating device fails to differentiate the young man's image from the multitude of conventional images that it is modeled on. The ceremonious vocabulary and tone of Sonnet 7 sound alien to the lover's idiom that the previous sonnets have worked so hard to establish, so that the more the sonnet sermonizes the young man, the more even the most duteous readers' eyes are inclined to turn away from the young man's image, fulfilling the couplet's prophecy of an "unlooked on" beloved.

Readers may very well content themselves with such an alteration of their view of the beloved's image as long as they, like Vendler, consider Sonnet 7 as a conventionally boring literary exercise with only "word-games" to salvage it, ${ }^{114}$ or as long as, like Fineman, they use Sonnet 7 to highlight how Shakespeare's use of imitation uses difference to differentiate itself from a conventional, idealizing form of mimesis. However, an amorous reading of Sonnet 7, one that conceives of

110. Fineman, p. 260.

111. Fineman, p. 261.

112. Fineman, p. 355

113. Fineman, p. 261.

114. Cf. Vendler, p. 77, "It was perhaps because his topics here were so entirely conventional that Shakespeare looked to word-games to put him on his mettle in composing the poem." 
the sonnet as a love poem and hence the utterance of an amorous "I," must account for the change in the lyrical "I's" tone and the alleged temporary breakdown in his imaginative faculties that combine in Sonnet 7 to place the beloved's previously so painstakingly cultivated image in the blind spot of both the poet's and the readers' eyes.

"The lover's discourse is usually a smooth envelope which encases the Image, a very gentle glove around the loved being. It is a devout, orthodox discourse," 115 Roland Barthes says in what could serve as an apt description of the "gracious" and "sacred" "homage" that Sonnet 7 appears to be to the "majestic" image of the young man as he is likened to the sun at the "highmost pitch" of "his golden pilgrimage." However, as described above, Sonnet 7 alters this image by simultaneously likening the succession of the young man's glory to its own decline, subverting the referential frame of the sonnet's feudal metaphors and thereby "exposing" the young man "as subjected to an instance which is itself of a servile order ..., yielding to worldly rites by which some sort of recognition is hoped for." 116 Procreation is once again revealed as an inadequate means of preserving the beauty of both the young man and his image, since the very act of engaging in the rite of breeding in order to protract the recognition of his beauty would also shatter the young man's image as the "gracious" sun, making him appear as a mere vassal to time, an "under-eye" that is forced to acknowledge the glaring triviality of its brightness in the glittering light of the real thing: a sun that does not need to reproduce itself to shine anew.

This is a conclusion that Sonnet 7 does not shy away from but, appropriately, blushes to formulate: the shame entailed in procreation, the blasphemy $y^{117}$ of eternalizing one's self by pointing to one's own mortality in such a commonplace manner, is palpable in the abrupt clumsiness of Sonnet 7's couplet and its pun, symptomatic of an amorous "I's" "horror of spoiling" 118 his beloved's image and paving the way for the gradual undoing of procreation as a metaphor for soulmaking in the subsequent sonnets.

115. Barthes, p. 28.

116. Barthes, p. 26.

117. Cf. Barthes, p. 28, "When the Image alters, the envelope of devotion rips apart; a shock capsizes my own language ... A blasphemy abruptly rises to the subject's lips and disrespectfully explodes the lover's benediction; he is possessed by a demon who speaks through his mouth, out of which emerge, as in the fairy tales, no longer flowers, but toads. Horrible ebb of the Image. (The horror of spoiling is even stronger than the anxiety of losing.)"

118. Barthes, p. 28 


\section{DÁNIEL BODONYI}

\section{Sonnet 8}

The alteration of the beloved's image, Barthes says, is like "a counter-rhythm: ... a syncope in the lovely phrase of the loved being." 19 This counter-rhythm is what an amorous reading registered in Sonnet 7 and what the "well-tunèd sounds" of Sonnet 8 profess to offset. However, as Fineman observes, the "true concord" of Sonnet 8 bespeaks the same "excess of likeness" that has been causing a rift in the poet's vision and the young man's "I" from the beginning of the procreation series:

On the one hand, the "mutual ordering" of the fruitful lute "resembles" the concordantly nuclear triangle of "sire, and child, and happy mother." On the other hand, however, this is a marriage of true minds that makes each one of these three - "sire, and child, and happy mother" - too much "resemble" one another. Because each string is "sweet husband to another," there is an excess of likeness in the "all in one" of the lute's "true concord." 120

On the contrary, the perlocutionary effect of this carefully orchestrated yet not quite wohltemperiertes unison manifests itself as an excess of difference: the young man is both annoyed and delighted by the melody - but, paradoxically, remains consistently and blatantly indifferent to the words - of what, in yet another less-thanobvious oxymoron, is characterized as a "speechless song" on the merits of procreation. This difference, which is intrinsic to the poet's lute as much as to the young man's "discordant unity," 121 is further amplified through the lyrical "I's" binoculars as it observes, with obsessive relish, the minutest reactions that his own recital elicits from his beloved. Such excessive vigilance, Luhmann says, is the upshot of the totalizing experience a passionate lover undergoes:

Taking excess as the measure of love provided the basis for a new set of considerations. Above all, love totalizes. It makes everything that has something to do with the beloved, even trifling, appear relevant, and thus bestows a value on everything that enters its field of vision. The totality of the beloved's inner experience and activities demand continuous observation and assessment in terms of stereotyped oppositions such as love/indifference or sincere/insincere love. ${ }^{122}$

119. Barthes, p. 25.

120. Fineman, p. 257.

121. Cf. Fineman, p. 259, "The young man embodies a discordant unity. . . And so too does the lute itself, whose sounding and moral both belie each other."

122. Luhmann, p. 68. 
The implicit question Sonnet 8 seeks to answer, therefore, is whether the young man is a loving or an indifferent other. But to answer that question, the young man must first decide whether the sonnet can be interpreted as a sincerely amorous utterance. In the context of Sonnet 8 , this is not an analytical but a musical question: by understanding Sonnet 8 as a "speechless song," a passionately contrapuntal Lied ohne Worte, the young man can decipher the true meaning of the sonnet's elaborate theatricality, the staged setting in which the lyrical "I" is looking anxiously at his beloved's face as he listens to his lute, hoping that he will respond to the melody but remain indifferent to the message of his tune.

In this respect, Vendler's observation that "the true intent of the verbal imagination is always to make a chain of interesting signifiers, with the 'message' tucked in as best the poet can," 123 is spot-on: Sonnet 8 is concerned with signs, which "are not proofs," 124 and hence it "falls back, paradoxically, on the omnipotence of language ... a the sole and final assurance." ${ }^{125}$ Sonnet 8 is a failed rhetorical exercise: the lyrical "I" too "confounds ... the parts that [it should] bear." But its failure is a testament to Shakespeare's greatness in both the art of poetry and the art of seduction since neither the verbal, nor the passionately amorous imagination needs justification ${ }^{126}$ for its excessiveness; both are self-referential ${ }^{127}$ because "in both poetry and love, reality is what is created." ${ }^{28}$

\section{Sonnet 9: Summary}

The first eight procreation sonnets point to the presence of an amorous "I" implicitly but with increasing momentum as the rhetorical force of the procreation argument is gradually subdued by the poetic logic and language of seduction. It is not until the couplet of Sonnet 9 that the word "love" is first mentioned in the procreation series, giving the young man and the reader an unequivocal indication of what is at stake for the first time. The sonnet, however, says nothing about love; it only presents its negative image - the likeness of a "makeless," "issueless," formless, weeping and wailing world banished from the bosom of beauty and of love.

123. Vendler, p. 82.

124. Barthes, p. 215.

125. Barthes, p. 215.

126. Cf. Luhmann, p. 70, "[A]ll the justifications given for love failed in the final instance. To give some definite reason would be to contradict the spirit of love."

127. On the self-referentiality of the code for amour passion, see Luhmann, pp. 67-70, or Shakespeare, A Lover's Complaint, lines 264-266, "O most potential love; vow, bond, nor space / In thee hath neither sting, knot, nor confine, / For thou art all, and all things else are thine."

128. Frye, p. 31. 


\section{DÁNIEL BODONYI}

But is it really the world that the young man's lack of thrift is causing to suffer? In the sonnet's peculiar frame of reference, it is "on himself" that the young man "such murd'rous shame commits," undermining the apparent treatise on love as an instrument of the common good. Ultimately, the young man is urged to show his love for others by reproducing for his own sake, which adds a twist to the procreation argument: the young man must reproduce out of love for others but not necessarily with the other that he loves. Sonnet 9 is significant in the amorous narrative because it explicitly calls upon the young man "to prove his love in his role as lover" 129 without specifying the identity of his other, and thereby it creates suspense that only the explicit appearance of the Sonnets' amorous "I" and the rhyming of "me" with "thee" will dissipate in Sonnet 10.

In my analysis of the first nine procreation sonnets, I have attempted to show that the entry on stage of the lyrical "I" in Sonnet 10 and, specifically, his entry on stage as a lover are not random occurrences; rather, they result from a methodical carving out of the passionate lover's position in a traditionally epideictic discourse. Drawing and expounding on Joel Fineman's analysis of Shakespeare's use of mimesis in the young man sonnets, I have attempted to illustrate how the initial procreation sonnets break with the idealizing practice of mimesis by using metaphor to introduce difference in the sameness of the procreation argument. In addition, I have attempted to point out different ways in which this metaphorical mimesis infuses the individual sonnets' syntax and rhetoric by pointing to the presence of an "I" that construes itself as an amorous soul in the making and as a model for his other's soul-making.

By no means do the resulting readings of Sonnets 1-9 constitute attempts at complete commentary: there is a lot more to be said about each sonnet. What this paper has tried to illustrate through these readings is that each of these sonnets can be read amorously, that is, as an utterance by an as-yet-implicit but more and more audaciously amorous "I." These amorous readings are metaphorical: each of them uses key metaphors from the sonnet under scrutiny to accentuate the ways in which these metaphors enter into contradictions with the sonnet's rhetorical claims. In addition, I have also attempted to point out similarities between the sonnets' metaphors and those used by Roland Barthes in his representation of $A$ Lover's Discourse to underpin the sense of familiarity an amorous reader will experience when reading the procreation sonnets. I see this parallel as further justification for Fineman's claim that the subjectivity developed in Shakespeare's Sonnets is a prototype for the modern subject of love as passion - a claim that I have also tried to illustrate with passages from Niklas Luhmann's analysis of how this type of subjectivity developed in the context of the social code for love.

129. Luhmann, p. 71. 
Admittedly, such metaphorically imitative readings of the Sonnets will resort to hypothesizing a certain amount of ingeniousness and role play on the lyrical "I's" part. However, I believe this is a more elegant way of resolving the apparent conflict between the initial procreation sonnets' oratory and poetics since it allows the reader to reanimate and relate to each of these sonnets as instances of amorous poetry, rather than forcing him or her to write some of them off as "fanciful" études on Shakespeare's part in the art of sonneteering. This is how the amorous readings proposed in this article differ from the predominantly formalist approaches adopted by critics like Helen Vendler, whose brilliant observations this paper has nevertheless also relied on extensively since its aim is not to argue against such readings, but to build on their insights, follow up their misgivings, and thereby present an alternative to them, retracing the pathways of desire that lead to the appearance of an amorous "I" in Shakespeare's procreation sonnets. 